\title{
Edmodo as An Online Instructional Delivery Technique for Sustaining Teaching and Learning Activities in Covid-19 Era in Public Universities in North-Central, Nigeria
}

\author{
Martin Afen Olofu ', Paul Agbade Olofu 2* \\ 1 Department of Curriculum Studies, Faculty of Education, University of Calabar, 540271 Calabar, Nigeria \\ 2 Department of Continuing Education \& Development Studies, Faculty of Education, University of \\ Calabar, 540271 Calabar, Nigeria \\ *Corresponding author: paulagbade@gmail.com
}

Received: 15 July 2021; Accepted: 15 August 2021; Published: 23 August 2021

\begin{abstract}
This study centered on Edmodo as an online instructional delivery technique for sustaining teaching and learning activities in covid-19 era in public universities in North-Central, Nigeria. The study was guided by two objectives and two research questions and one hypothesis. This study adopted descriptive survey and quasi-experimental research designs. The sample of the study comprised 100 students in two universities (each for treatment and control groups) and 7008 lecturers drawn from three public universities in North-Central, Nigeria. Stratified and simple random sampling techniques were used for selecting universities and the sample of the study. First, stratified sampling was used to group both lecturers and students into two strata. Thereafter, simple random sampling was used to select the universities and sample of the study; using lottery method with replacement. 10\% proportionate sample was used to select the lecturers. Curriculum Studies Achievement Test (C-SAT) and questionnaire were used as instruments for data gathering. Data collected were analyzed with simple percentage, mean and t-test statistical techniques. Finding showed that the level of awareness of university lecturers on Edmodo as a technological instructional delivery technique is very low or poor. It was also indicated that there is significant difference between the mean achievement scores of university students taught curriculum studies with Edmodo and their counterparts taught with lecture technique; as those in the treatment group performed better than those in control group. The study recommended that: school management, the government and ICT-related Non-governmental organizations should help in organizing workshops and seminars for lecturers in order to advance their knowledge and awareness on ICT usage especially Edmodo and others. Also, since the students who were taught with Edmodo significantly performed better than their counterparts in the control group who were taught with lecture method, lecturers should be encouraged to use Edmodo for teaching and learning.
\end{abstract}

Keywords: Edmodo, Emerging Technology, Teacing and Learning, Covid-19

\section{INTRODUCTION}

Technological innovation has created great impact on every level education; as online courses, teaching aids, educational softwares, social networking tools and other emerging technologies are disrupting and almost taking over the traditional physical classroom environment. Thus, educational administrators, teachers and other educational stakeholders having good knowledge of emerging technologies and how they actually impact on teaching and learning especially during covid-19 era remains very critical; as it determines the extent to which emerging technologies are being frequently, continuously and sagaciously employed in the educational system. Therefore, Edmodo as an emerging technological educational tool in the 21st century according to Çankaya, Durak and Yünkül (2013) cited Sylvester (2020) 
remains one of the fundamental and must-used instructional delivery approaches that should be employed by teachers for sustaining teaching and learning activities especially during covid19 era. This is so to say because the platform promotes communication, collaboration and coaching opportunity for schools and teachers. It also enables teachers to share content, distribute quizzes, assignments and manage communication with students, colleagues and parents. Edmodo it enables teachers to really bring the classroom online. With the ability to give assignments, quizzes and polls to students, Edmodo users can manage their classes and consolidate all of their activities in one place.

The concept of Edmodo as an emerging technological educational tool is a premier social media and learning platform for teachers and students alike. According to Kongchan (2013) in Adams (2019), Edmodo is a blended learning platform which is used by many educational institutions all over the world for its attracting features; as it is user-friendly, free and secure online environment, top teaching and learning websites developing innovation and creativity; literacy learning and communicating facility. Puspitaloka, Rachmawati and Octaviyenty (2015) cited in Adebayo (2020) defined Edmodo as a social media platform for schools that attracts teachers and students. It is a global education network that helps connect all learners with the people and resources needed to reach their full potential.

Historically, Edmodo was founded in September 1, 2008 with its headquarters at San Mateo, California. The site has since gained over 20 million users. The users of edmodo at its formative stage were non-educational organizations such as Index Ventures, Benchmark, Greylock Partners, Learn Capital, New Enterprise Associates, Union Square Ventures, Glynn Capital Management, Tenaya Capital, SingTel Innov8 and KDDI. The platform was used to educate their staff and share other relevant organizational contents to staff members. Edmodo is available in several languages such as Arabic, English, Croatian, Spanish, Portuguese, German, Greek, French, Italian, Turkish, Dutch, Chinese, Swedish and Indonesia (Adebayo, 2020).

In 2013, Edmodo was included in the list of the top applications for teachers by PC Magazine. That same year, Edmodo acquired a startup, Root-1, in an attempt to become the application store for education. Vibhu Mittal, Co-founder and CEO of Root-1, became the CEO of Edmodo in 2014. For instance, 28 secondary school teachers in Croatia reported to have used edmodo for teaching their students. In Spain, 42 higher education teachers had used edmodo for instruction as of 2014 while 29 upper level students in Italia admitted to have been interacted with their teachers through edmodo. In 2014, Edmodo launched Snapshot-a suite of assessment tools to measure student progress on educational standards. Ed-tech digest awarded Edmodo Snapshot the Cool Tool award for best assessment solution. The company has partnered with two major publishers in United Kingdom, Oxford University Press and Cambridge University Press to provide access to educational content on the Edmodo Platform and brought Edmodo Snapshot to the UK (Greg, 2017).

Edmodo is designed to connect and collaborate within the educational environment and it is easily installed on computers, laptops and android. It also collaborates and connects, shares content and allows students to get access homework, school notices and grades. It also enables exceptionally secure cloud-based collaboration. A teacher or school can easily manage a system that provides the best features of the cloud while practically eliminating the anxiety which is often associated with students on the internet (Lampard, 2018). In the view of Evenddy and Hamer (2016) cited in Luiz (2019), teachers use Edmodo as an online blackboard and inbox to post polls, quizzes and assignment guidelines and invite students to submit finished assignment. For the student, edmodo can be used to collaborate their projects, ask questions and working together for the purpose of learning. It provides practical ideas on how to approach and plan for young learners' courses as well as materials and ideas for specific activities. It will develop the awareness of what children aged 5 to 12 are capable of, what they enjoy and what strategies work best to motivate them to learn. In this course, the student will learn planning for young learner classes, it is about creating optimal conditions for learning, 
lesson planning, presenting and practicing language, using a course book, storytelling, games and activities, projects-based learning.

Commenting on the relevance of edmodo as an instructional strategy during covid-19, Okafor (2020) maintained that even though the educational system was caught unawares by the outbreak of corona virus, the utilization of edmodo as a technological instructional approach has a whole lot of potentials; as it affords teachers, students and parents to interact amidst corona virus. Okafor also added that with edmodo, teachers and students at all levels can conveniently, constantly and continuously engage in teaching-learning process via online even at the peak of corona virus since the teachers and students do not converge in the four walls of classroom. Beyond students and teachers using Edmodo, parents can also get the option to log in either as their children or themselves. They can review their children's work, grades and more. They can also receive updates from their children's teachers regarding missed assignments and school happenings.

In the same vein, Labaran (2019) stated that the use of Edmodo as an instructional approach has great potentials during covid-19 and the outbreak of any pandemic; as it helps teachers and students to always come online and carryout teaching and learning without spreading the virus since they are not expected to have physical contact with one another. With edmodo during covid-19, parents could assist their children/wards who cannot independently make use of computer and its related facilities to learn. Thus, edmodo remains very a fundamental platform through which educational institutions could employ during covid-19 to ensure the sustainability and continuity of learning activities without any form of having physical contact. Batz (2020) reported that many educational institutions in countries such as Finland, Canada, Malaysia, Ghana and Japan etc were to continue their educational activities even in the midst of covid-19 due to some educational technological platforms such as Google classroom and edmodo. Batz added that edmodo allowed teachers during covid19 to share instructional videos and other digital contents with their students. Teachers were able to use edmodo during covid-19 to create learning groups for their students, give them assignments, mark and give feedbacks to the learners.

According to Cunningham (2013) cited in Adams (2019), the application of Edmodo in teaching helps educators, students and even parents to always access Edmodo when they need it. Users also have unlimited options in terms of sharing digital content; as teachers can embed instructional videos, create learning groups for students, and manage calendar events. The platform offers numerous organizational features for teachers, even offering an option for users to print out rosters for substitutes. Badges are another fun feature, allowing educators to monitor the progress of student groups and issue awards for their achievements. Enterprising educators can even use Edmodo to connect with other classrooms around the globe. Whether they are studying a foreign language, history, economics or another subject, partnering with a class online can be both socially engaging and culturally rewarding for students. With Edmodo, students also have a whole lot to benefit from the Edmodo as an educational technological tool; as they can access extra help from peers, instructors or school-tube. It further enables students to turn in work for their teachers' review and as well, get instant feedback, including teacher annotations. Beyond being able to join groups for clubs, sports and other activities, students can learn how to safely and appropriately interact online.

According to Cauley (2013) cited in Sabastine (2019), one of the educational websites that takes the ideas of social network and makes it appropriate for a classroom is Edmodo; as it helps students and teachers to connect with one and another by sharing ideas, problem, and useful tips. By using Edmodo, students can get help from the entire class, and teachers can assign and grade work. In addition, Edmodo allows parents to join and to check the progress in a study of their children. Inappropriate content and spam cannot reach Edmodo because teachers can identify everything that is posted on Edmodo. Giving and submitting assignments can be held virtually. Thompson (2018) maintained that through Edmodo, students' score can be recorded by teachers. Meanwhile, students and parents have accessibility to check student's 
progress in study. By using Edmodo, teachers are also able to provide quiz, polling, and post topic for discussion among students. Edmodo provides the ability for students to present and to post their assignment because space for place student work is also provided. All grades and badges that the students get are accessible for the teachers, the parents and the students themselves.

In the opinion of Puspitaloka, Rachmawati and Octaviyenty (2015) cited in Elvis (2020), the use of Edmodo in the educational setting by teachers and students is very much likely to promote a a secure and close relationship and conducive learning environment. The message board of the platform allows easy secure and open communication that can be monitored and controlled by the teacher. It is easy to monitor students' interaction and teachers can post assignments and assessments that are electronically submitted and automatically graded. A built-in survey tool can be used to check for understanding. Teachers and other school personnel can create professional groups, subject area communities and other networks to extend professional development. It also allows teachers and students to easily store and share documents and files in a wide variety of formats in a cloud-based environment. Teachers can as well maintain a personal content library and share content with members. Students can instantly access their files 24/7 through their cloud-based library. Folder-sharing as a feature of the platform allows teachers to share all content for particular units of study with select groups or all students. It also allows parents to create an account to connect with their child's groups.

Commenting on the level of awareness of lecturers on the existence and usage of Edmodo, Dobler (2019) observed that so many lecturers even in the 21st century have little or no idea at all about what the term Edmodo entails. In his opinion, some lecturers have neither heard the word before let alone using the platform for teaching students. In the same vein, Olabanjo (2016) cited in Marcus (2019) maintained that a whole lot of university teachers in Nigeria are not ICT compliant; as some cannot even boot a computer system not to talk of using ICT related applications. In his opinion, "Edmodo as an ICT learning package may not havebeen employed by some university teachers despite its huge benefits to both teachers and students. Olabanjo therefore, submits that school management needs to do enough in the area of training and retraining its teachers on the usage of modern ICT related packages or applications in order to facilitate teaching and learning.

Okafor (2020) posit that though Edmodo as an online learning strategy is relatively new in its existence but a whole lot of lecturers are unawares of its existence, usage and benefits. In his view, only a few university teachers who are ICT compliant may be aware of the existence and usage of Edmodo. Okafor admitted that even in the 21st century, some lecturers are still not computer literate; making it highly difficult for them to employ ICT in teaching. Hence, depriving university students from benefitting from the huge potentials inherent in the application of ICT in teaching and learning. Greg (2017) similarly admitted that Edmodo has not been fully used by educationists. The reason for this in the view of Greg is because a lot of educationists are either not fully aware of its usage or not aware at all of its existence.

Corona virus first started in Wuhan City, China in December, 2019 and it was subsequently declared by the World Health Organization on 30th January and 11th March, 2020 as a public health emergency of international concern and a global pandemic respectively. Due to its wide spread and the ravaging nature of the pandemic on human lives, countries across globe declared total lockdown in every aspect of the economy. Thus, there was serious interruption and discontinuity in the teaching-learning process in all levels of education in Nigeria and across the globe. The disruption was so severe that students could not continue with their studies. Okafor (2020) observed that the declaration of covid-19 pandemic lockdown by the Federal Republic of Nigeria posed serious threat to the educational system; as all educational institutions had to suspend their educational activities; thereby altering school calendar. 
Therefore, the was need for the educational system at all levels to devise means of sustaining its learning activities via the application of several emerging technological tools while still curtailing the spread of covid-19. It is on the basis of the above narrative that this study examined Edmodo as an innovative online educational tool for sustaining teaching and learning activities in covid-19 era in in public universities in North-Central, Nigeria.

This study sought to achieve two specific objectives: (i) to ascertain the level of awareness of university lecturers about Edmodo as a technological instructional delivery technique; (ii) to determine the difference between the mean achievement scores of university students taught curriculum studies with Edmodo and their counterparts taught with lecture technique. The hypothesis is: there is no significant difference between the mean achievement scores of university students taught curriculum studies with Edmodo and their counterparts taught with lecture technique.

\section{METHOD}

This study adopted descriptive survey and quasi-experimental research designs. Descriptive survey research design was chosen and considered suitable for the present study because data were collected from representative sample of the larger population; thereby guaranteeing generalization of the findings to the larger population. On the other hand, the choice of quasi-experimental design was because the researcher does not have control over the treatment but studied the pre-existing groups that received the different treatments after the fact. Thus, the design used both control and experimental/treatment groups.

The sample of the study comprised 100 students in two universities (each for treatment and control groups) and seven hundred and eight (708) lecturers drawn from three public universities in North-Central, Nigeria. Stratified and simple random sampling techniques were used for selecting universities and the sample of the study. First, stratified sampling was used to group both lecturers and students into two strata. Thereafter, simple random sampling was used to select the universities and sample of the study; using lottery method with replacement. $10 \%$ proportionate sample was used to select the lecturers. Curriculum Studies Achievement Test (C-SAT) and questionnaire were used as instruments for data gathering. Curriculum Studies Achievement Test consisted of 40 multiple objective questions while the questionnaire for lecturers contained just an item with a 4point measuring scale of Very High, High, Low and Very Low. Data collected were analyzed with simple percentage, mean and t-test statistical techniques. While simple percentage and mean were used to ascertain the level of awareness of university lecturers on edmodo as instructional technological approach, t-test was used to test the hypothesis. As for the mean score, the decision rule or benchmark for the acceptance or rejection of an item was 2.5 and above while for the t-test, the decision rule was that when the calculated value is greater than the table or critical value, the null hypothesis is rejected while accepting the alternative.

\section{Data Analysis}

Data collected were subjected to descriptive statistical analysis; using simple percentage and mean score. Research Question One: What is the level of awareness of university lecturers about Edmodo as a technological instructional delivery technique?

Data in table 1 ascertained the level of awareness of university lecturers on Edmodo as a technological instructional delivery method. To analyze the data, simple percentage and mean score were used. Data revealed that only 41 respondents represented by $5.8 \%$ had very high awareness on Edmodo, 89 respondents represented by $12.6 \%$ had high awareness on Edmodo, 233 respondents represented by $32.9 \%$ had low awareness on Edmodo while an overwhelming respondent of 345 represented by $48.7 \%$ had very low awareness on Edmodo. Going by the percentage value and decision rule, it can be implied that the level of awareness of university lecturers on Edmodo as a technological instructional delivery approach is very low or poor. 
Table 1. Level of awareness of secondary school teachers on Edmodo as a technological instructional delivery method

\begin{tabular}{|c|c|c|c|c|c|c|c|}
\hline Item & $\begin{array}{l}\text { Very } \\
\text { High } \\
4\end{array}$ & $\begin{array}{l}\text { High } \\
3\end{array}$ & $\begin{array}{l}\text { Low } \\
2\end{array}$ & $\begin{array}{l}\text { Very } \\
\text { Low } \\
1\end{array}$ & Total & mean & $\begin{array}{l}\text { Decision } \\
\text { Rule }\end{array}$ \\
\hline $\begin{array}{l}\text { Kindly rate } \\
\text { yourself on the } \\
\text { level of your } \\
\text { awareness of } \\
\text { Edmodo as an ICT } \\
\text { instructional } \\
\text { strategy. }\end{array}$ & $\begin{array}{l}41 \\
5.8 \%\end{array}$ & $\begin{array}{l}89 \\
12.6 \%\end{array}$ & $\begin{array}{l}233 \\
32.9 \%\end{array}$ & $\begin{array}{l}345 \\
48.7 \%\end{array}$ & $\begin{array}{l}1242 \\
100 \%\end{array}$ & 1.8 & Rejected \\
\hline
\end{tabular}

Hypothesis One: There is no significant difference between the mean achievement scores of university students taught curriculum studies with Edmodo and their counterparts taught with lecture technique.

Table 2. Two-tailed t-test on the Mean Achievement Scores of Experimental and Control Groups

\begin{tabular}{lcccccccc}
\hline Group & N. & Mean & SD & df. & $\begin{array}{l}\text { Cal- } \\
\text { Value }\end{array}$ & $\begin{array}{l}\text { P- } \\
\text { value }\end{array}$ & $\begin{array}{l}\text { Sig. } \\
\text { Lev }\end{array}$ & Decision \\
\hline $\begin{array}{l}\text { Experimental } \\
\begin{array}{l}\text { Group } \\
\text { Control Group }\end{array}\end{array}$ & 54 & 70.69 & 8.82 & 98 & 9.152 & 1.633 & 0.05 & Rejected \\
\hline
\end{tabular}

Data in table 2 determined the difference between the mean achievement scores of university students taught curriculum studies with Edmodo and their counterparts taught with lecture technique. To analyze the data, $t$-test was used for data analysis. Data revealed that the calculated value is 9.152 while the $p$-value is 1.152 at 0.05 level of significance. The decision rule states that when the calculated value is greater than the table or critical value, the null hypothesis is rejected while accepting the alternative. Since the calculated value of 9.152 is greater than the $p$-value of 1.152 , the null hypothesis which states that there is no significant difference between the mean achievement scores of university students taught curriculum studies with Edmodo and their counterparts taught with lecture technique is rejected. Thus, there is significant difference between the mean achievement scores of university students taught curriculum studies with Edmodo and their counterparts taught with lecture technique; as those in treatment group performed better than their counterparts in control group.

\section{RESULT AND DISCUSSION}

Data in Table 1 ascertained the level of awareness of university lecturers on Edmodo as a technological instructional delivery technique. Result showed that the level of awareness of university lecturers on Edmodo as a technological instructional delivery technique is very low or poor; as $48.7 \%$ of the respondents agreed that they had very low awareness on Edmodo. The above finding agrees with the opinion of Dobler (2019) who observed that so many lecturers/teachers even in the 21st century have little or no idea at all about what the term Edmodo entails. In Dobler's opinion, some teachers have neither heard the word before let alone using the platform for teaching students. In the same vein, Olabanjo (2016) cited in Marcus (2019) maintained that lecturers in Nigeria especially those in rural areas are not ICT compliant; as some cannot even boot a computer system not to talk of using its related applications. In his opinion, "Edmodo as an ICT learning package has not been employed by most lecturers despite its huge benefits; as a whole lot of them are even ignorant of the package. Olabanjo therefore, submits that school management needs to do enough in the area of 
engaging lecturers on the usage of modern ICT related packages or applications in order to facilitate teaching and learning.

Okafor (2020) posit that though Edmodo as an online learning strategy is relatively new in its existence but a whole lot of lecturers are unawares of its existence, usage and benefits. In Okafor's view, only a few lecturers who are ICT compliant may be aware of the existence and usage of Edmodo. Okafor admitted that even in the 21st century, some teachers are still not computer literate; making it highly difficult for them to employ ICT in teaching. Greg (2017) similarly admitted that Edmodo has not been fully used by educationists. The reason for this in the view of Greg is because a lot of educationists are either not fully aware of its usage or not aware at all of its existence.

Data in table 2 determined the difference between the mean achievement scores of university students taught curriculum studies with Edmodo and their counterparts taught with lecture technique. Finding indicated that there is significant difference between the mean achievement scores of university students taught curriculum studies with Edmodo and their counterparts taught with lecture technique; as those in the treatment group performed better than those in control group.

The above finding corroborates with the view of Cauley (2013) cited in Sabastine (2019) who maintained that the application of Edmodo in teaching helps in creating learning groups for students and manage calendar events, enables students to turn in work for their teachers' review and as well get instant feedback. It also helps students to learn how to safely and appropriately interact online. Cauley cited in Sabastine also stated that Edmodo helps students and teachers to connect with one and another by sharing ideas, problem, and useful tips. By using Edmodo, students can get help from the entire class and teachers can assign and grade work. Thompson (2018) posited that through Edmodo, students' score can be recorded by teachers. Meanwhile, students and parents have accessibility to check student's progress in study. Edmodo provides the ability for students to present and to post their assignment because space for place student work is also provided. All grades and badges that the students get are accessible for the teachers, the parents and the students themselves.

\section{CONCLUSION}

Edmodo remains one of the fundamental and must-used instructional delivery techniques that should be employed by university lecturers in order to sustain teaching and learning activities especially during post covid-19 era. In line with findings of the study, it was concluded that some university lecturers within the study area have very low or poor level of awareness on Edmodo as a technological instructional delivery strategy. The study also concluded that the use of Edmodo positively impacts on university students' academic performance.

\section{ACKNOWLEDGEMNET}

We remain very grateful to all the scholars and researchers whose ideas and information were used in writing this paper. Our appreciation also goes to the trained research assistant who helped in data collection and collation.

\section{REFERENCES}

Adams, L. (2019). Edmodo as a learning platform. Journal of Educational Technology, 3(2), $116-124$.

Adebayo, U. (2020). Redefining teaching and learning via technological strategies: Edmodo in perspective. Ibadan: Ayaz Limited.

Batz, L. (2020). Edmodo and covid-19 era school instruction across countries. London: Education World. 
Cox, J. (2017). Hacker steals Millions of user account details from education platform edmodo. Retrieved from www.enwikipedia.org.

Dobler. A. (2019). Flattening classroom walls: Edmodo takes teaching and learning across the globe. Retrieved from www.reading.org.

Greg, M. (2017). Millions of identities stolen from education platform Edmodo. Retrieved from www.enwikipedia.org.

Labaran, K. (2019). Edmodo as an instructional approach and covid-19. Journal Innovative Learning, 4(1), 221-229.

Lampard, A. (2018). Edmodo and its benefits in educational setting. London: Macmillan.

Luiz, O. (2019). Edmodo as a multi-task educational platform. New York: Macmillan.

Marcus, E. (2019). Lecturers' level of awareness of edmodo as instructional strategy in the $27^{\text {st }}$ century. Awka: Chuks Limited.

Okafor, D. (2020). Corona virus lockdown: A challenge to the educational system in Nigeria. Enugu: Sage.

Sabastine, S. (2019). Application of edmodo in teaching and learning. Journal of Instruction and Dvelopment, 2(1),303-312.

Sylvester, T. (2020). Edmodo and teacher instruction. Benin: Jack Press

Thompson, H. (2018). The edmodo quick start guide. Retrieved from www. Google.org.

Wan, T. (2014). Edmodo raises $\$ 30 m$ round led by Index Ventures. Retrieved from www.enwikipedia.org.

WHO (2020). Infection prevention and control during health care when covid19 is suspected. www.who.int.publications.

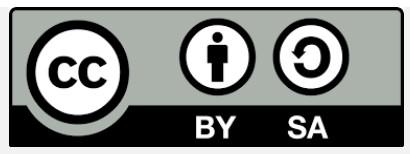

Copyright (c) 2021 by the authors. This work is licensed under a Creative Commons Attribution-ShareAlike 4.0 International License. 